Отримано: 26 травня 2019 року

Прорецензовано: 31 травня 2019 року

Прийнято до друку: 6 червня 2019 року

e-mail: annalyt@ukr.net

DOI: $10.25264 / 2519-2558-2019-6(74)-221-223$

Hanna Lytnieva,

Candidate of Pedagogical Sciences (PhD),

Associate Professor at the Department of Foreign Philology and Translation, Kyiv National Transport University

\title{
ASYNDETIC TECHNICAL TERMS AND THEIR TRANSLATION IN AUTOMOBILE CONSTRUCTION SPHERE
}

The article deals with the adequate translation of Asyndetic Technical Terms (ATT) in the Automobile Industry Sphere. Special terms generally correspond to a single concept in the investigated sphere and play a substantial role in the construction and development of technical terms. There can be suggested several ways of ATT faithful translation into the target language. Three componental ATT can be rendered into Ukrainian by the following approaches:

- beginning with the adjective, after the head noun and its adjunct - camshaft gear drive- шестерний привід розподільного валу;

- beginning with the initial adjective followed by the adjunct and then the head noun-major autumn transport cотрапу- головна осіння транспортна компанія;

- reverse order translation, beginning with the head noun followed by attributive component and the adjunct noun - relative wear resistance index - відносний показник опору зношення;

- in a descriptive way, condensed ATT needs more words in the target translation to render their meaning - radiator top header - вepxня з'єднувальна сериевина радіатору.

During the study of ATT, their types and features were also investigated. An analysis of 300 terms was conducted in the automobile construction sphere. During this researching it was found out that three-component ATT were predominant and amounted to $42 \%$ (frequency index). So it may be stated, that the multicomponent technical terms occupy the leading role in English automobile industry field terminology.

Summarizing all the above, it should be noted that English terms transfer to the Ukrainian language requires knowledge of the field related to translation, terms content understanding in English and terminology knowledge in the native language.

Key words: terminology, asyndetic technical terms, translation, three-component ATT, structural type.

Литнєва Ганна Павлівна,

Кандидат педагогічних наук, доцент кафедри іноземної філологї̈ та перекладу, Національний Транспортний Університет, Київ

\section{АСЕНДИТИЧНІ ТЕХНІЧНІ ТЕРМІНИ ТА ЇХ ПЕРЕКЛАД В ГАЛУЗІ АВТОМОБІЛЕБУДУВАННЯ}

У статті розглянуто проблему адекватного перекладу асендитичних технічних термінів (АTT) в галузі автомобілебудування В сучасних мовах наукова термінологія становить значний шар лексики, який забезпечує ефективну комунікачію в різних сферах діяльності людини. Термінологія - відкрита мовна система у якій невпинно з'являються все нові й нові терміни. Особливо справедливе дане ствердження є для автомобільної галузі, що зазнала інтенсивного становлення та розвитку. Машинобудування існує як окрема технічна галузь протягом тривалого часу, однак ї̈ термінологія не є предметом широкого спеціального наукового дослідження. Особливий інтерес в иій галузі викликають асендитичні технічні терміни та їх переклад на українську мову. АТT належать до шести структурних типів. Згідно проведеного аналізу найбільш вживаним (частотним) типом структур виявився Adjective + Noun $+N o u n(A+N+N$.) Аналіз текстів галузі машинобудування виявив у дослідженій $A+N+N$ структурі превалювання трикомпонентних ATT, які становлять 42\% від проаналізованих термінів. При перекладі иих термінів слід звернути увагу на специфіку перекладу трикомпонентних АТТ,які становлять значні труднощі при перекладі технічних текстів й потребують описового звороту або вдалого словосполучення при перекладi.

Ключові слова: термінологія, асендитичні технічні терміни, переклад, трикомпонентні АТT, структурний тип.

The research of technical terms translation is one of the most topical issues not only in linguistic sphere but also in business.

The automobile industry has historically been a trend-setter for many standards in the global marketplace and economy. Partially this is because the industry is made up of well-settled companies, and partially it's because it is a global industry that comes into contact with people in every nation.

It is also linked to the development of international relations between different states, in particular in the field of science and technology for further study of the means and methods of translation of complex terminological constructs, which is very important in the translation of texts and terms of technical direction. New terms should be included in the lexical language fund and enrich the terminology system of individual branches [9, p.157], in our case in Automobile Construction sphere.

The aim of the article is to study and analyze the most frequently used asyndetic technical terms in automobile industry texts and define the ways of their translation into the Ukrainian language.

It should be noted that in this sphere a specific term has a different semantic meaning, which may coincide with or may differ from the common language. It is worth mentioning that the change in the meaning of the term is influenced by language and extra-linguistic factors [7, p.85]. So we may state that a term is a word or a combination of words, which define a notion (subject, a phenomenon, property relation or process) that is characteristic for the given field of science, technology or the sphere of social life.[3, p.54]. Many dictionaries use a large number of explanations for the term. They are mostly pretty similar and differ in detail only. Terms appear in a particular environment. Their appearance cannot be accidental, but must comply with the norms of the word-formation of the national language. New, well-defined terms are included in the lexical language fund and enrich the terminology system of individual branches. 
It is important that the new breed meets the following requirements during the new term creation: the term must be unambiguous; only one name should correspond to one concept; similar values of the concept should be expressed by one term; the term should be stylistically neutral and correspond to the word-formation and syntactic rules of the given language [6, p.72]. Terms differ from the general usage words by definite semantic limitations and specific meanings peculiar only to them, a term does not only fix the concept by its notion, but specifies it from adjacent components. For better functioning, terms must express systematization of notions, express their essence and be semantically neutral and at the same time be unambiguous, accurate and precise.

Contemporary English has a host of asyndetic technical terms (clusters) that are often used in technical texts, in magazines and newspapers. Such terms are called multicomponent, which consist of several components.[1,p.13].For example, compact car platform - компактна автомобільна платформа, тисh-тоотеd baby G-Wagen - найбільш дискусійна модель автомобіляпозашляховика, higher roofline - висока лінія даxy, steeply raked C-pillar - круто нахилена задня стійка кузова легкового автомобіля, urban air pollutants - повітряні забруднювачі у містах, urban transport problems - міські транспортні проблеми.

So what is the asyndetic technical term? Asyndetic technical terms are word-groups consisting of two, three or more nouns, the translation of which is rather complicated. Irrespective of the number of components in their structure they are always in subordinate relation to each other, i.e. they function as adjunct (attributive component) and head (nucleus). [5, p.225], [3, p.217].

Asyndetic clusters are often preceded by adjectives, participles, pronouns, numerals in the function of attributes. They usually form with the noun components distinct sense units, which may predetermine the way of approach to the translation of clusters. [8, p.112]. According to their structure, all terms are subdivided into:

- simple terms, which consist of one word: congestion- перевантаження, gasoline-бензин, pressure-тиск, vehicle-транспортний засіб, engine-двигун, freightage-вантаж.

- fused (connected) terms, where separate components can be either terms or ordinary words, but together they create a stable terminological unit: fuel flow - потік палива, urban freight - міський вантаж, public transport - громадський транспорт.

- multicomponent terms. Such terms can have three, four and more components. There is a great number of such terms in technical texts and the ways of their translation into the target language have not yet been properly investigated. That is why the main aim of this thesis is to analyze multicomponent terms and the ways of their translation into Ukrainian: ultra-thin anti-glare layer надтонкий матовий прошарок, a collapsible trailer hitch - прогин по величині контейнера, shallow service trench - невелика комунікаційна мережа, water washout grease test - випробування здатності мастила протидіяти вимиванню водою.

There exist 6 structural types of asyndetic technical terms. [4, p.92.] These terms belong to the following structural types: $\mathrm{N}+\mathrm{N}$, $\mathrm{A}+\mathrm{N}, \mathrm{N}+\mathrm{N}+\mathrm{N}, \mathrm{A}+\mathrm{N}+\mathrm{N}, \mathrm{N}+\mathrm{N}+\mathrm{N}+\mathrm{N}, \mathrm{A}+\mathrm{N}+\mathrm{N}+\mathrm{N}$. Speaking about two component terms it should be stressed that there is a great number of such ATT in technical literature:

Compression volume - об'єм камери стискання, piston's throw - хід поршня, block trade - торгівля великими партіями.

Two- component terms of $\mathrm{A}+\mathrm{N}$-type are typical attributive word-combinations:

Short-time rating - короткочасна потужність, bevel gearing - конічна зубчаста передача, joint stock - акціонерний капітал, bid price - ціна пропозиції.

The translation of two-componential ATT of NN and AN-types may not present great difficulties while translating them into Ukrainian and may start: - with the head noun, - with the adjunct (A-type) or with the head (N-type), - in a descriptive way.

Translation of three, four, five, ect. multicomponential ATT is of great difficulty and presents a lot of problems for the translators in the technical oriented texts.

Let us consider one of its 6 types which are mostly commonly used in automobile technical texts: A+NN, AN+N $(-1,-2,-3$ in the numerical order) $[5, \mathrm{p} .232$.] It should be mentioned that asyndetic technical terms of $\mathrm{A}+\mathrm{NN}$ and $\mathrm{AN}+\mathrm{N}$ structure form distinct sense units of mentioned 2 types. The semantic interrelation between the componential parts of ATT is often quite complicated. The same concerns their structural complexity. It admits of no doubt, that each lexeme in ATT adds some new meaning to its general semantic structure. So, the more lexemes the ATT consists of, the more complicated the ways of its translation into the target language. As has already been said, there may be different approaches to rendering the lexical meaning of ATT. The following main factors influence these approaches: the semantic relations between the constituent parts of ATT; the number of nouns making up ATT; the structure of the adjunct and head; the presence or absence of the preceding adjectival component. It should also be mentioned that the following three factors can define the adequate translation of ATT: - the lexical meaning of the component parts; - their structural form; - the meaning of the cluster as a whole. Now let us consider the translation of technical terms of A+NN- type. Technical terms can be rendered into Ukrainian by the following main approaches:

- In the 1-3-2 order: beginning with the initial adjective after the head noun and its adjunct noun are translated in succession: camshaft gear drive - шестерний привід розподільного валу, huge surface area - величезна площа поверхні, multiple transportation modes - різноманітні способи перевезення.

- In the 1-2-3 order: beginning with the adjective after which the adjunct and then the head noun are translated in succession: major autumn transport campaign - головна осіння транспортна кампанія, public transport systems - громадські транспортні системи, micro-sized inorganic fillers - активні неорганічні наповнювачі, long-term temperature record - довгострокові температурні дані.

- In the 3-1-2 order: a considerable number of lexically transparent asyndetic clusters of the A+NN-type are translated in reserve order, i.e. beginning with the head noun after which attributive component and the adjunct noun are translated in succession: relative wear resistance index - відносний показник опору зрушення, public transport inadequacy - неадекватність громадського транспорту, internal combustion engine - двигун внутрішнього згорання.

- In the 3-1-2, 1-2-3 or 1-3-2 order: some asyndetic clusters of the type may be semantically condensed. As a result, more words are needed in the target language to render their meaning, i.e. they are to be translated in a descriptive way: radiator top header - верхня з'єднувальна серцевина радіатору, box -hopper machine - машина з дном що розкривається, surface vibratory compaction - ущільнювання за допомогою поверхневої вібрації, е-сommerce fraud - шахрайство при здійсненні комерційних операцій за допомогою Internet, freightage transit negotiations - перемови з приводу транзитного перевезення вантажу. 
So, we have illustrated different types of $\mathrm{A}+\mathrm{NN}$ terms translation. Now we shall pass to $\mathrm{AN}+\mathrm{N}$ analysis. These two types of word groups previews the choice of their translation. For instance, in the substantival clusters as: -relative wear resistance-відносний опір зношення; final car races-фінальні автогонки, the adjectival components modify the NN head components forming with them word groups of the A+NN structure. In the examples like: traffic control computer -комп'ютер для керування дорожнім рухом, wear test data - тестові дані амортизаціï; - the attributive components form close sense units of the AN+N structure with the head noun. As we have already given the possible ways of A+NN-type translation, we shall try to analyze the AN+N-type of ATT in which the initial adjective (A) and the following adjunct noun form a sense unit of their own. This unit functions as a semantically and syntactically single attributive component of the head noun. In contrast to the A+NN-type clusters, the AN+N-type clusters are generally translated starting with the head noun after which the attributive component and then the adjunct noun are translated. The most frequently used order of their translation is the following: 3-2-1, 3-1-2:

delivery goods notice - повідомлення про поставку товарів; vacuum brake cylinder - циліндр вакуумного гальма; human resource management -управління трудовим ресурсом; Monte-Karlo simulation - моделювання методом Монте-Карло; ВlackScholes model - модель Блека-Шоулза; exchange rate fluctuation - коливання валютного курсу.

A number of AN+N-type asyndetic technical terms are mostly translated in a descriptive way. It becomes necessary when ATT is used to denote a notion of English or American character not understandable to the Ukrainian speaking audience and there exists no other way of convening its sense into the target language:

California Bearing Ratio - Каліфорнійський коефіцієнт несучої спроможності; unconfined compression test - випробування на стискування без додаткового стискування; health care fraud - шахрайство у сфері охорони здоров я; electric drive vehicles - транспортні засоби з електричним приводом; non-vessel operating common carrier - оператор загального розподілення, що не володіє тоннажем; door-lock warning lamp - контрольна лампа, яка сигналізує про те, що двері відчинено.

Analysis of 300 asyndetic technical terms was conducted in the automobile construction sphere. During this researching it was found out that the number of two component terms amounted to $25 \%$ ( 75 units), three component- $42 \%$ (126 units), four component - 13\% (39 units), five component - 13\% (39 units), and multicomponent only $7 \%$ (21 units).

Analysis proved that three-component terms were most oftenly used in the samples of English language technical magazines; although generally in the technical orientation texts two-component terms are most commonly used, the least are the polycomponental terms.

So, it was statistically proved that the first place as to their occurrence

in technical matter texts is occupied by the three-componential ANN-type asyndetic technical terms, which split into two main subgroups. The first one constitutes the A+NN-type cluster and the second makes up the AN+N-type cluster in which the final noun form the head component to the initial AN group.

In English automobile industry field terminology the multicomponent terms occupy a leading role.

Terms that serve to define precisely the concepts in the field of science and technology are the highest category of names. Most researchers and scientists admit that terminology is one of the main scientific style stylistic features, an informative core of vocabulary of the science language [2, p.57].

The English terms transfer to the Ukrainian language requires knowledge of the field related to translation, terms content understanding in English and terminology knowledge in the native language. The translator should search the corpora of the source language and target one to find the usage of the term and its possible translation in its own linguistic context.

Summarizing all the above, the need of translation and language services in the automobile industry has a vast reach nowadays.

\section{References:}

1. Kestel B. R. Chainsaw Operator's: Manual. The Safe Use of Chainsaws Sixth Edition. Cross-cutting (Basic competence for safe operation). Australia: Landlinks Press, 2017. № 6. P.13.

2. Kacher G. Stuttgart civil war. Car UK. UK: Routledge, 2017. № 6. P. 57.

3. Karaban V.I. Translation of English Scientific and Technical Literature. Vinitsa: Nova Knyga Publishing House 2001. P. 217.

4. Коптілов В. В. Теорія та практика перекладу. Київ: Видавництво Київ. Університету, 1982. Р. 92.

5. Ilko Korunets. Theory and Practice of Translation. Vinitsa: Nova Knyha Publishers 2001. P. 225.

6. Matvias L.G. Course of Modern Ukrainian Literary Language: Morphology. Kyiv: State Educational and Pedagogical Publishing House "Soviet School" 1962. P.72.

7. Nida E. Componental Analysis of Meaning. The Hague-Paris: Moton, 1975. P. 85.

8. Sandler P. L., Stott C. L. Manage with English. Oxford University Press: London, 1984. P.112.

9. Superanska O. V. General terminology: Questions of theory. Moscow: Science, 1989. P. 157. 